\title{
COPING WITH CYSTIC FIBROSIS IN THE REPUBLIC OF MACEDONIA -PARENT PERSPECTIVE
}

\author{
Tatjana Zorcec ${ }^{1}$, Nada Pop-Jordanova ${ }^{2}$, \\ Stojka Fustik ${ }^{1}$, Tatjana Jakovska ${ }^{1}$, Lidija Spirevska ${ }^{1}$ \\ ${ }^{1}$ University Children's Hospital, Skopje, North Macedonia \\ ${ }^{2}$ Macedonian Academy of Sciences and Arts, Skopje, North Macedonia
}

Corresponding author: Nada Pop-Jordanova, Bul Krste Misirkov br.2, P.O.Box 428, 1000 Skopje, North Macedonia, e-mail: popjordanova.nadica@gmail.com

\section{ABSTRACT}

Introduction: Cystic fibrosis $(\mathrm{CF})$ is a progressive, life-threatening, genetic disease which mainly damages the lungs and the digestive system. It's a complex medical condition, with several individual forms and variation in the symptoms severity. Few factors such as age of establishing the diagnosis, the number and the type of infections and their management, best treatment options, comorbid conditions etc. can influence the patient's overall health, disease progression and quality of life. Many CF patients will reach adulthood, so coping with the chronic disease is very important for the overall health and everyday living. Aim of the study: To screen the quality of life in CF patients in the Republic of Macedonia, from the parent perspective.

Subjects and methods: In the study we have included 55 parents of CF patients. We have created a questionnaire, specially designed for this survey, with questions related to their everyday coping with $\mathrm{CF}$ and quality of life.

Results: The majority of the parents refer to the overall typical social and emotional life of their children, addressing some difficulties concerning the financial aspect of the disease and still significantly having fear from the stigma in the society.

Conclusion: CF patients and their families in the Republic of Macedonia must overcome many obstacles on daily basis. Despite that, they can still have full and meaningful lives.

Keywords: cystic fibrosis, chronic illness, quality of life

\section{INTRODUCTION}

Cystic fibrosis (CF) is the most common genetic disease in Europe. It is a chronic, progressive and life-shortening disease. Life expectancy has increased substantially in recent decades, due to early diagnosis and improved treatment.

The treatment is life-long and includes special regime of everyday living, using various medications and increased calorie intake. Those treatments and way of living are complex, require serious amount of time each day, as long as the patient is alive, and often can cause difficulties for the families and patients. Recent therapeutic advances have improved the life expectancy and the quality of life of people suffering from CF. Child's quality of life is closely linked to school integration and success. 
It is well known that people with chronic health conditions are at risk for psychological distress. Psychosocial factors may impact the course of chronic conditions, such as CF. Previous research demonstrated that health-related quality of life domains may predict the survival in children and adults with $\mathrm{CF}$ [1].

So, quality of life $(\mathrm{QoL})$ is considered increasingly important. QoL is a broad multidimensional concept that usually includes subjective evaluations of both positive and negative aspects of life. It should be assessed periodically and monitored by the multidisciplinary team of professionals.

In the last several decades life expectancy for CF patients has increased dramatically, due to earlier diagnosis and more advanced treatments. In the past, CF patients had much shorter life expectancy, but in present time most of them will reach adulthood [2]. With the improvement in life expectancy, supporting patients and their families in living with CF has become increasingly important [3].

Living with CF may cause fear, anxiety, depression and stress. Although $\mathrm{CF}$ requires daily care, most people who have the disease are able to attend school or work, have normal social and emotional life.

\section{AIM OF THE STUDY}

The aim of the study was to screen the quality of life in CF patients in the Republic of Macedonia, from the parent's perspective.

\section{SUBJECTS AND METHODS}

The study was conducted at the Cystic fibrosis centre, University children's hospital in Skopje, in the period from May to August, 2015. A total of 55 parents of CF patients were included in the study.

We have created specially designed questionnaire with 33 questions, addressing the everyday life of CF patients and their parents. The questions addressed demographic data, personal life, self-perception, daily $\mathrm{CF}$ treatments, interpersonal relations, economical status of the families etc. Parents were asked to fill in the questionnaires regarding the quality of life of their children. Qualitative data from the questionnaires were analysed. The questionnaires were filled in at a clinic visit and took between 20 and 30 minutes to complete. All questionnaires were self-administered by the parents.

\section{RESULTS}

General data of the CF patients and parents group

In the study we included 55 parents of children with CF (44 male v.11 female), with mean age of 8.4 $\pm 6.88 \mathrm{SD}$ (range 2.3-17.1 years). Most of the parents who answered the questionnaire were mothers $(87 \%), 11.11 \%$ were fathers and $1.85 \%$ other members of the family. The mean age of the mothers was 35 $\pm 9.21 \mathrm{SD}$ (range 18.3-55.1 years) and of the fathers $38 \pm 3.33$ (range 19.7-59.3 years). $87 \%$ of the parents were married, $9 \%$ were divorced, in $2 \%$ one of the parents was deceased, and $2 \%$ of the parents were with undefined status (Pie no.1).

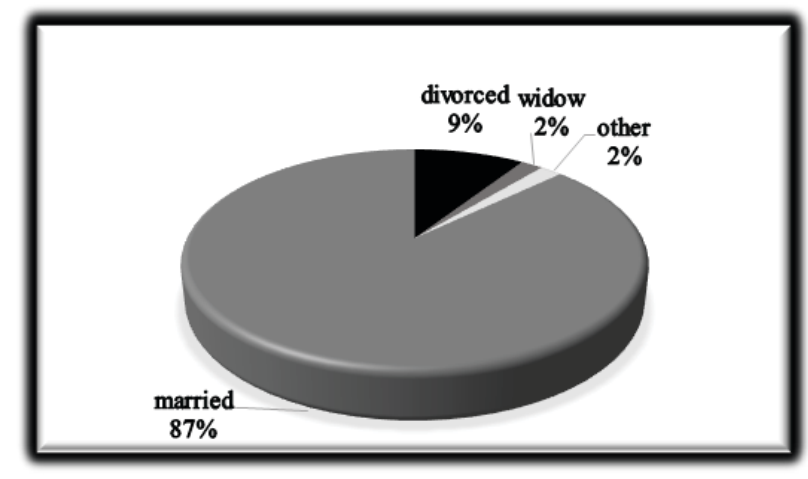

Pie no. 1. Marital status of the $C F$ parents

Analysis of the educational level of the mothers showed that $42 \%$ of this group has finished secondary school, 35\% elementary and 22\% have bachelor degree (Pie no. 2).

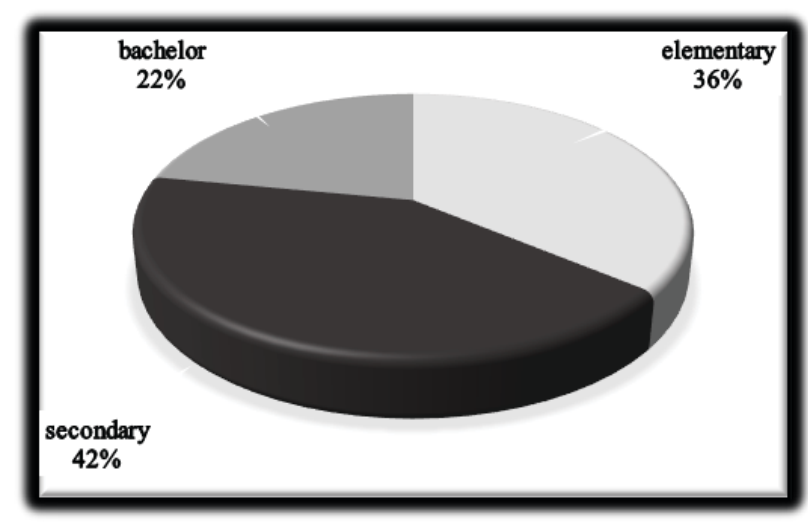

Pie no. 2. Educational level of the CF mothers 
Analysis of the educational level of the fathers showed that $68 \%$ of this group has finished secondary school, $15 \%$ elementary and $17 \%$ have bachelor degree (Pie no. 3).

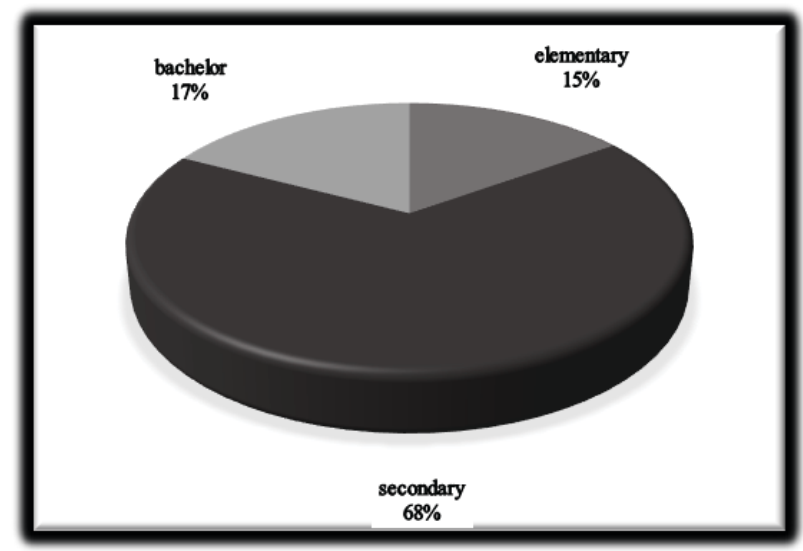

Pie no. 3. Educational level of the CF fathers

$36 \%$ of the parents had a full time job, $26 \%$ did not work, because of the child's disease, $18 \%$ worked occasionally, $10 \%$ were looking for a job, in $6 \%$ they had a part time job and $4 \%$ of them were not looking for a job at all (Graph no. 1)

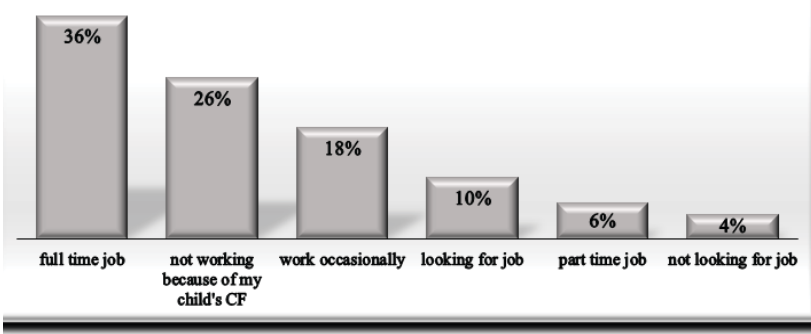

Graph no. 1. Working status of the CF parents

$63 \%$ of the parents have declared their socio-economic status as satisfactory, $26 \%$ as good and $11 \%$ as bad (Pie no. 4).

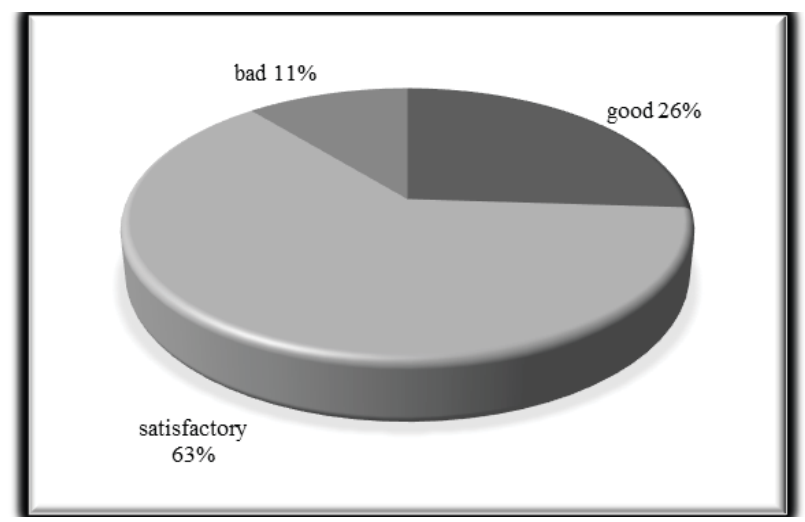

Pie no. 4. Socio-economic status of the CF families
About the question if the family has financial difficulties to cover the necessary therapy, $47 \%$ declared that they have no financial problems, $45 \%$ sometimes have problems and $8 \%$ have problems very often (Pie no. 5).

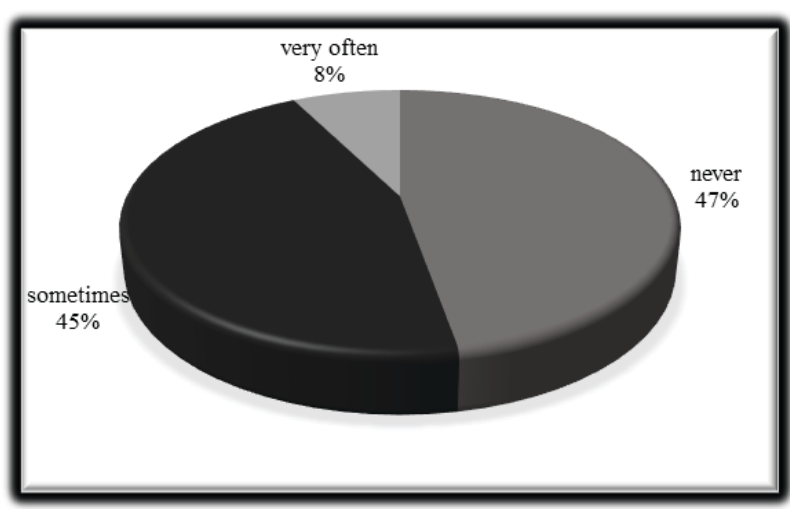

Pie no. 5. Lack of finance for needed therapy patients

Results concerning health issues of the CF

The general health of the CF patients was characterized as good most of the time (50\%), $44 \%$ as moderate and $6 \%$ had bad health. (Pie no. 6).

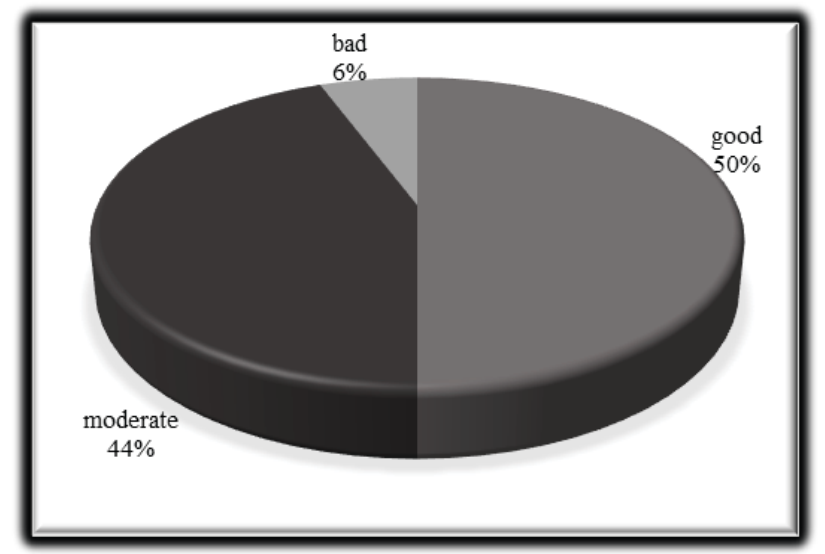

Pie no. 6. General health condition of CF patients-parent perception

General mood of the CF patients was defined as fine in $90 \%$, sad and worried were $4 \%$ and angry and irritated were $6 \%$ of the cases (Pie no. 7 ). 


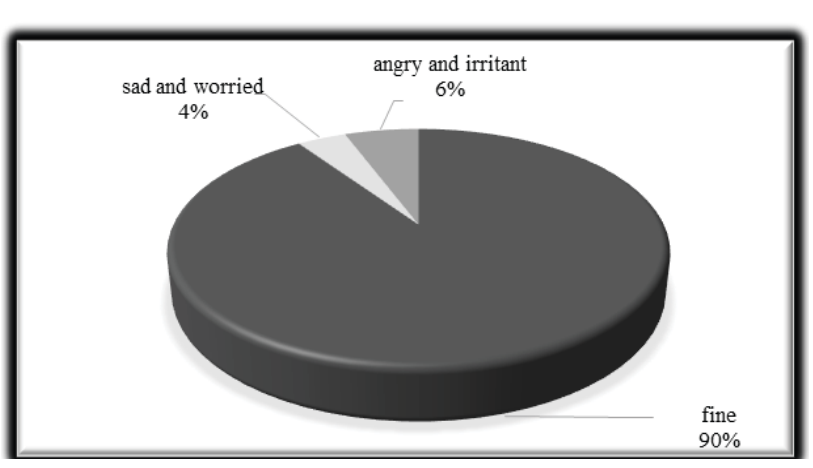

Pie no. 7. General mood condition of CF patients-parent perception

Concerning the level of strength and energy, $77.36 \%$ was estimated as normal, $16.98 \%$ moderate and $5, .66 \%$ as poor. (Graph no. 2).

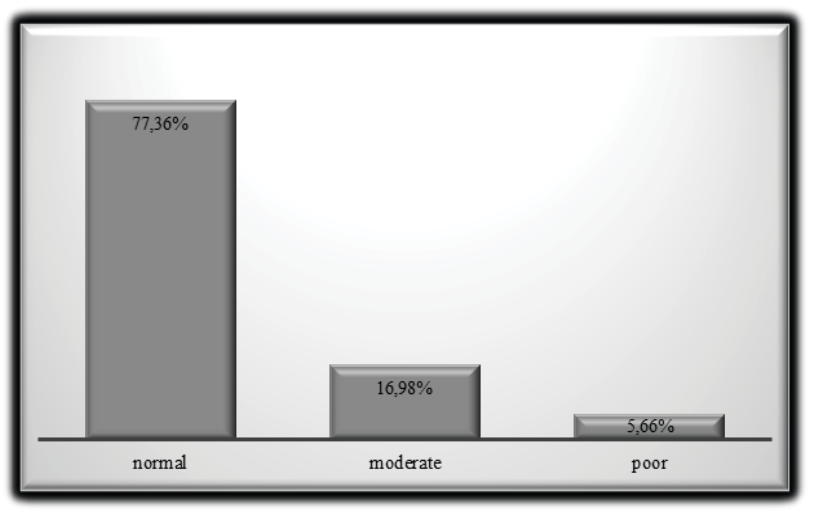

Graph no. 2. General level of strength and energy of $C F$ patients-parent perception

General mood influenced the treatment quality and consistency in 53\% CF patients, in 33\% it happened sometimes and in 14\% never (Pie no. 8).

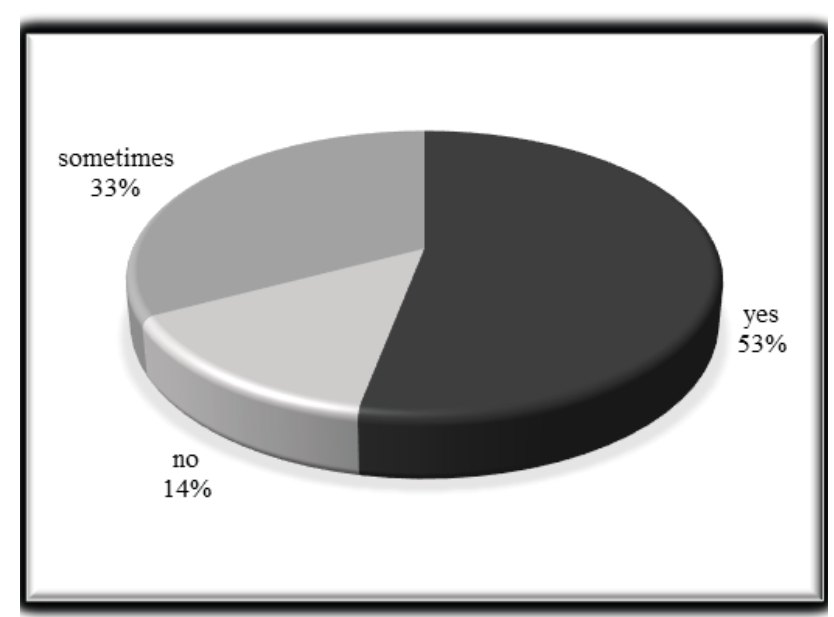

Pie no. 8. Influence of the general mood on treatment quality and consistency in CF patients-parent perception
Results concerning quality of family, social and school life of the $C F$ patients

Parents of CF patients reported that they didn't see any physical difference from the peers $(70 \%)$, $18 \%$ saw some difference and $12 \%$ saw clear physical difference (Graph no. 3).

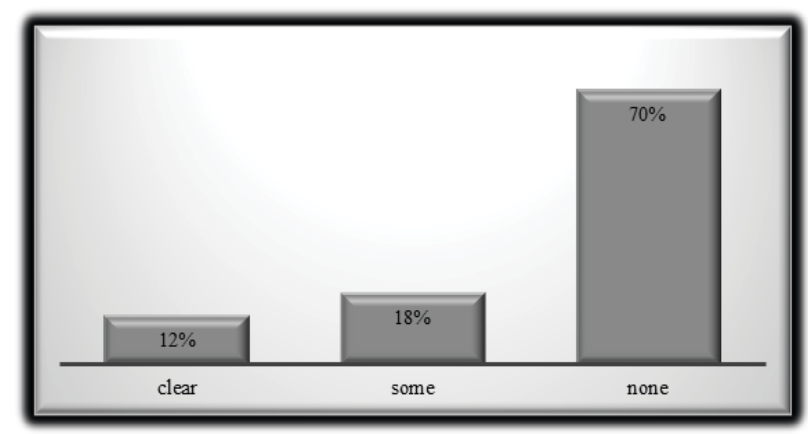

Graph no. 3. Physical difference from peers-parent perception

Concerning social contacts, the majority of the CF patients (88.23\%) were having good social contacts, $9.8 \%$ from time to time and $1.96 \%$ rarely. In $5961 \%$ those contacts were on daily basis, in 15 . $38 \%$ every other day, in $15.38 \%$ twice per week, in, 7. $69 \%$ once per week and in $1.92 \%$ even less (Table 1).

Table 1. Social contacts and their frequency

\begin{tabular}{|c|c|c|c|c|c|c|}
\hline & 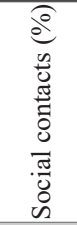 & 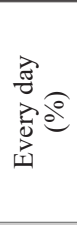 & 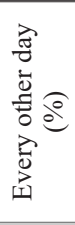 & $\begin{array}{l}\frac{y}{8} \\
\frac{8}{3} \\
\frac{0}{3} \\
0\end{array}$ & 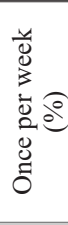 & 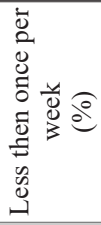 \\
\hline$\stackrel{\infty}{\infty}$ & 88.23 & 59.61 & 15.38 & 15.38 & 7.69 & 1.92 \\
\hline 苐 & 1.96 & & & & & \\
\hline 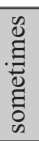 & 9.8 & & & & & \\
\hline
\end{tabular}

Concerning their absence from school, parents reported no difference from peers $(76 \%), 17 \%$ reported more frequent absences and 7\% much more than the peers (Graph no. 4). 


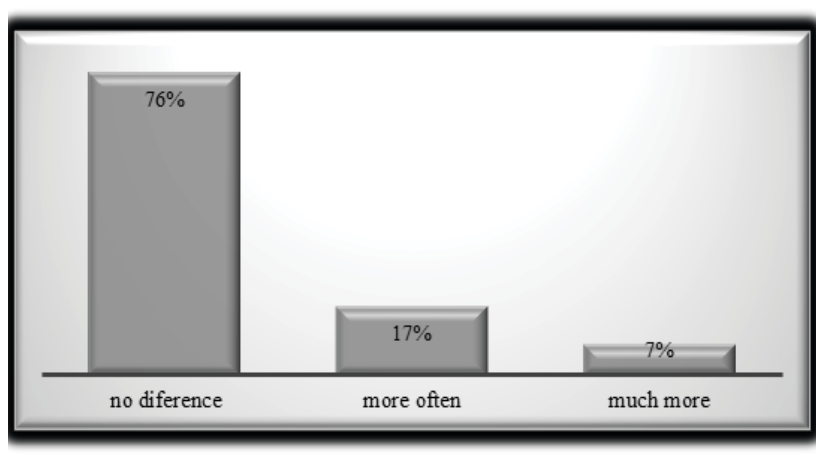

Graph no. 4. Schools absences compared to their peers

Parents of CF patients thought that daily therapies and treatments have no influence over the child's school and free time activities $(81 \%), 17 \%$ believe that they have moderate influence and big influence for $2 \%$ of the patients with cystic fibrosis. (Graph no. 5).

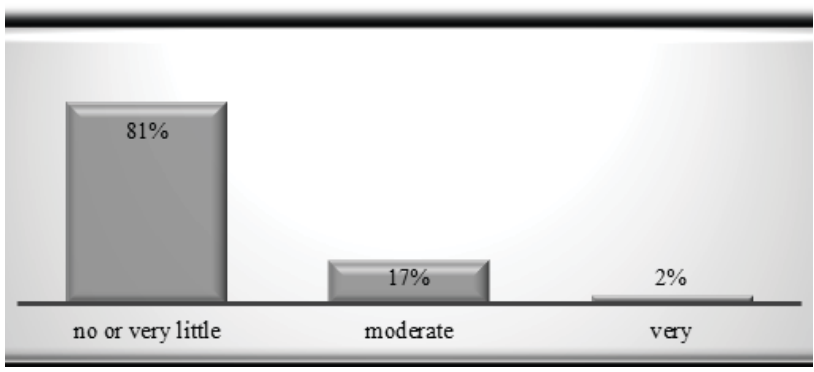

Graph no. 5. Influence of daily therapies and treatments on the child's school and free time activities

Embarrassment of sharing the information about the illness with others/family or receiving treatment in front of the friends/families, is shown at the table no. 2:
Table no. 2. Embarrassment of sharing the information about the illness with others/family and receiving treatment in front of the friends/family

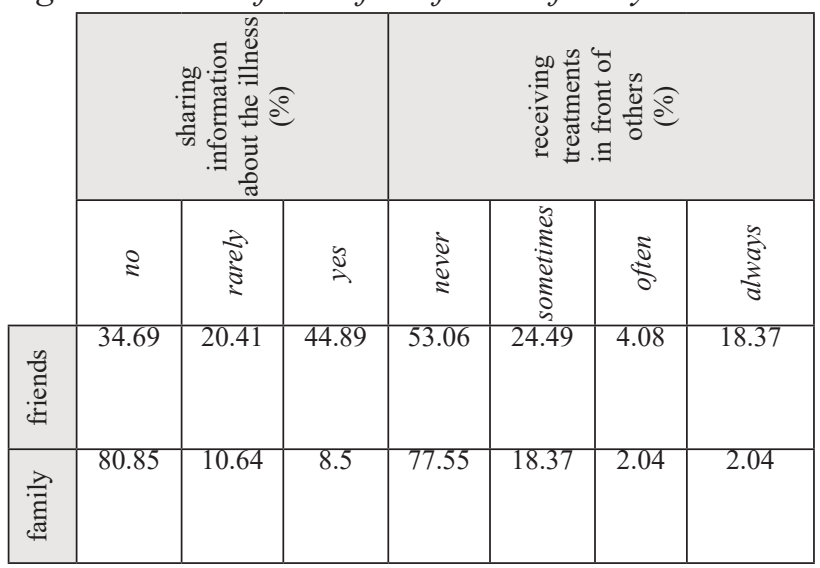

Overall, parents rated the quality of life in CF families, as good, but often burdened by the illness in $46 \%$, normal life in $40 \%$ and not good in $14 \%$ of the families (Graph no. 6).

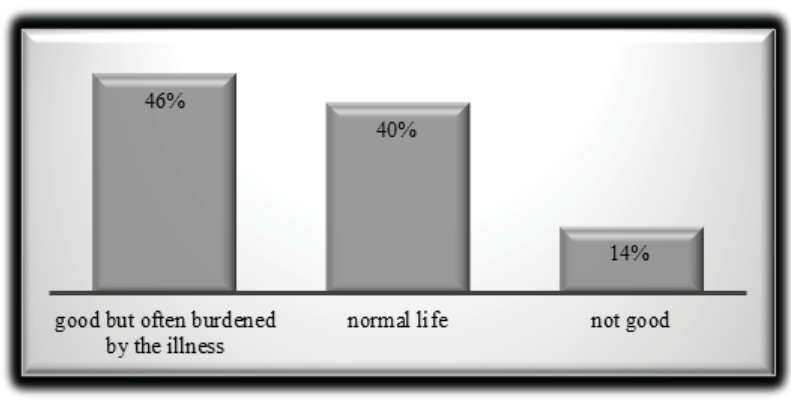

Graph no. 6. Overall quality of life in $C F$ families

Results concerning receiving daily treatments and therapies in $C F$ patients

Daily, the majority of the children (57.99\%) are spending one to two hours receiving treatments and therapies, up to one hour $28 \%$, two to three hours $10 \%$ and more than three hours $4 \%$ of the patients (Table no. 3).

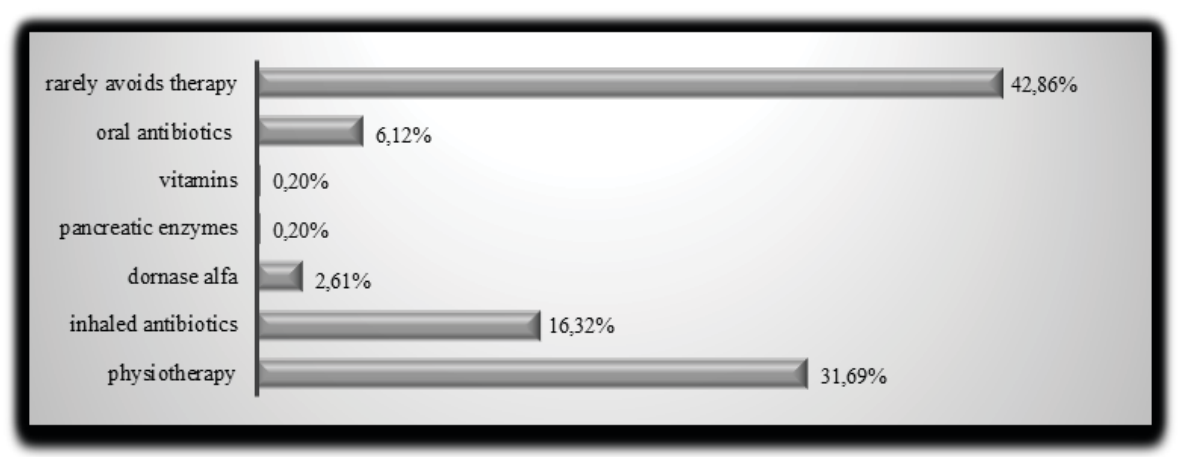

Graph no. 7. Difficult and avoiding treatments 
Table no. 3. Hours spent per day in all treatments

\begin{tabular}{|l|c|}
\hline up to one hour & $28 \%$ \\
\hline $1-2$ hours & $57.99 \%$ \\
\hline $2-3$ hours & $10 \%$ \\
\hline more than 3 hours & $4 \%$ \\
\hline
\end{tabular}

Regarding the question which therapy is the most difficult one and children avoid to do it, in 42. $86 \%$ cases children's parents reported that that rarely happened. If they were avoiding treatments, the most avoided were physiotherapy in $31.69 \%$ and inhalations with antibiotics in $16.32 \%$ of the patients (Graph no. 7).

If the treatments are avoided, in Table 4 we present reasons for such a behaviour:

Table no. 4. Reasons when the treatments are avoided \begin{tabular}{l|c}
$\begin{array}{l}\text { parents and child are too busy to do/receive } \\
\text { them }\end{array}$ & $16.66 \%$ \\
\hline $\begin{array}{l}\text { the child needs more time for friends or } \\
\text { electronic devices }\end{array}$ & $38 \%$ \\
\hline tiredness/not feeling good & $21.43 \%$ \\
\hline $\begin{array}{l}\text { parents don't believe in the treatment helping } \\
\text { the child }\end{array}$ & $2.38 \%$ \\
\hline $\begin{array}{l}\text { parents think skipping few treatments will not } \\
\text { harm the child }\end{array}$ & $21.43 \%$
\end{tabular}

Concerning the nutrition in this group of $\mathrm{CF}$ patients, parents reported that $48 \%$ of them have good appetite and enjoy in the process of eating, $42 \%$ enjoy the food and eat well periodically and $10 \%$ have a very bad appetite (Graph no. 8).

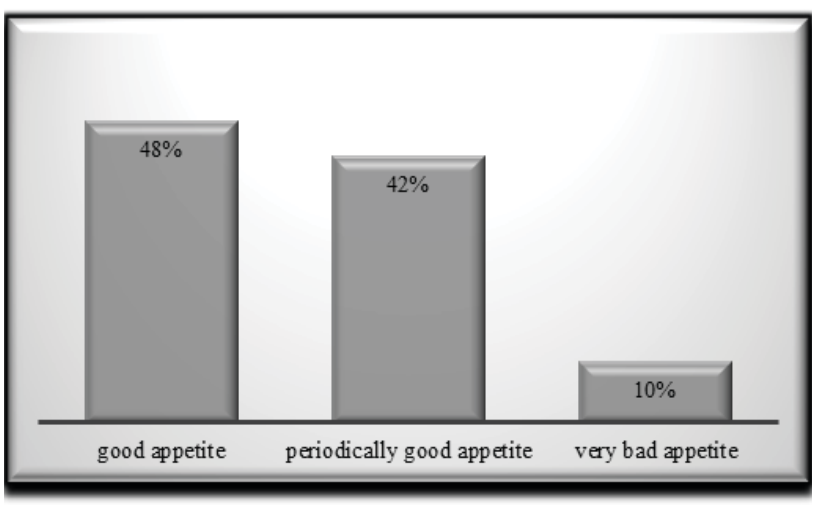

Graph no. 8. Nutrition in CF patients

\section{DISCUSSION AND CONCLUSION}

Generally, chronic illnesses are slowly progressing, lasting in many years and potentially limiting everyday life, level of functionality, productivity and overall quality of life. When a child has a chronic illness, one or both of the parents take a role of constant caregiver, often be- coming an expert of the disease by reading plentiful of literature and they still have to carry out the typical parenting role. Therefore, parents are facing many difficulties in managing the child's chronic condition in the settings of the daily life [4]. Concerning that parents can have particular influence on the child, the approach that parents will have in interpreting and reacting on the situations which affect the child, will influence the child's coping mechanisms and understanding of the situation. If the parents are able to relate the positive aspects of any given situation to a child (particularly the positive aspects of adverse situations) then the child's adaptation to and understanding of this situation may be facilitated [5]. Furthermore, with the improvement in life expectancy, support for the patients and families in adjusting to life with a chronic disease has become extremely important.

Our study showed that in this group of $\mathrm{CF}$ patients, the majority of the families remained compact and that the rate of divorce is very low (only $9 \%$ of the marriages are divorced). The majority of the parents stated that their socio-economic status was satisfactory but still had difficulties in concerning financial aspect of the disease. What is very unusual is that parents stated that high percentage of the children (90\%) were in a good mood most of the time and had no emotional problems. This could be result of good coping mechanisms among parents and patients and successful strategies in dealing with the condition. Parents report good social life, leisure activities and school time for their children. What is significant is that fear of sharing the condition with friends (35\%) and family members $(80 \%)$ is significant and fear of stigma is present.

We can conclude that in our group of subjects, despite the obstacles, CF patients and families must overcome in the everyday life, they still have full and meaningful lives. Large percentage of the families remained together, but have some financial difficulties, since small number have one parent who has a fulltime job. Almost all parents reported steady physical and psychological condition, good social life and steady school attendance. But still the fear from the stigma in the society is present and makes them less open to share experiences and to talk about health issues. Parents and CF children have no choice, but to live with this condition. The future is uncertain for them and they need to adjust to many adverse events. 


\section{REFERENCES}

1. Jennifer A Cronly, Alistair J Duff, Kristin A Riekert, Anthony P Fitzgerald, Ivan J Perry, Elaine A Lehane, Aine Horgan, Barbara A Howe, Muireann Ni Chroinin and Eileen Savage Health-Related Quality of Life in Adolescents and Adults With Cystic Fibrosis: Physical and Mental Health Predictors, Respiratory Care September 2018, respcare.06356; DOI: https://doi. org/10.4187/respcare.06356.

2. Scott C Bell and Philip J Robinson Exacerbations in cystic fibrosis: 2 - Prevention, Tho- rax. 2007 Aug; 62(8): 723-732. doi: 10.1136/ thx.2006.060897.

3. Cormac McCarthy, Orla O'Carroll, Alessandro N. Franciosi and Noel G. McElvaney Cystic Fibrosis in the Light of New Research, Published: August 24th 2015, DOI: 10.5772/59523, ISBN: 978-953-51-2152-7, Copyright year: 2015.

4. Staaba D., Wenningera K., Geberta N., Ruppratha K., Bissonb S., Trettinc M., Pauld K., Kellere K., Wahn U. Quality of life in patients with cystic fibrosis and their parents: what is important besides disease severity? Thorax. 1998; 53: 727-731.

5. Farrell M. Parents of critically ill children have their needs too! A literature review. Intensive Care Nurs. 1989 Sep; 5(3): 123-8.

\title{
Резиме
}

\section{СПРАВУВАҢЕТО СО ЦИСТИЧНАТА ФИБРОЗА ВО МАКЕДОНИЈА - РОДИТЕЛСКА ПЕРСПЕКТИВА}

\author{
Татјана Зорчец ${ }^{1}$, Нада Поп-Јорданова ${ }^{2}$, Стојка Фуштиќ 1 , \\ Татјана Јаковска ${ }^{1}$, Лидија Спиревска ${ }^{1}$ \\ ${ }^{1}$ Универзитетска клиника за детски болести, Скопје, Северна Македонија \\ ${ }^{2}$ Македонска академија на науките и уметностите, Скопје, Северна Македонија
}

Вовед: Цистичната фиброза (ЦФ) претставува прогресивна, животозагрозувачка, генетска болест, која најмногу ги оштетува белите дробови и дигестивниот систем. Таа претставува комплексна медицинска состојба, со неколку индивидуални форми и варијации на тежината на симптомите. Неколку фактори, како што се возраста на поставување на дијагнозата, бројот и видот на инфекциите и нивното менаџирање, најдобрите опции за третман, коморбидните услови итн. можат да влијаат на севкупното здравје на пациентите, прогресијата на болеста и на квалитетот на животот. Многу болни со ЦФ доживуваат возрасна доба, па затоа справувањето со хроничната болест е многу важно за севкупното здравје и секојдневното живеење.

Цел на студијата: Да се скринира квалитетот на живот кај болните од ЦФ во Република Македонија од перспектива на родителите.

Субјекти и метод: Во студијата се вклучени 55 родители на пациенти со ЦФ. Специјално за оваа студија направивме прашалник со прашања поврзани со секојдневното справување со болеста и квалитетот на животот.

Резултати: Најголемиот број родители реферираа речиси типични социјални и емоционални карактеристики на живот кај своите деца, со постоење извесни проблеми поврзани со финансиите поврзани со болеста и сѐ уште присутниот страв од стигматизирање во општеството.

Заклучок: Пациените со ЦФ и нивните семејства во Р Македонија мора да надминат голем број пречки во секојдневниот живот. И покрај тоа, тие можат да си обезбедат полн и значаен живот.

Клучни зборови: цистична фиброза, хронична болест, квалитет на живот 